\title{
ARTIGOS
}

\section{HOW THE DESIGN OF PRODUCT-SERVICE SYSTEMS CAN IMPROVE THE LIFE OF PEOPLE WITH VISUAL IMPAIRMENT}

\author{
RENATA DE OLIVEIRA CRUZ CARLASSARA | UNESP \\ JÚLIA LOPES KANO | UNESP \\ TOMAS QUEIROZ FERREIRA BARATA, Dr. | USP \\ MONICA MOURA, Dra. | UNESP \\ IANA ULIANA PEREZ,M.Sc.| UNESP
}

\begin{abstract}
The field of contemporary design has been changing its purposes and has increasingly been working in multiple areas. The technological capacity related to design has been allowing professionals to help people with various disabilities through assistive technologies. For this purpose, the Product-Service System (PSS) has been proven very much appropriate with its tools for creating solutions with an intense degree of concern for details and broad insight into the targeted matter. PSS is a user-centered design approach that also embarks discussions about social sustainability and environmental issues. This article aims to analyze a case study that resulted in the development of a solution through PSS. By the end, it presents a discussion about the advantages of this approach and how designing through PSS can provide solutions for visually impaired people.
\end{abstract}

KEY-WORDS: Contemporary Design; Assistive Technology. Social Sustainability. 


\section{INTRODUCTION}

Contemporary societies are based on complex systems that reflect the complexity of human experience in general, which is increasingly permeated by technology that came to stay. We reached a moment that is no longer possible to ignore the technology. There are arguments for and against it. For people with visual impairment, for instance, technology innovation has helped a lot and enabled some of the activities that in the past, they couldn't do. Design and technology are walking together, even in a less-stuff-more-people world. Society is going on a path based on use, not ownership, and this happens because "the aim to ensure adequate living standards of the rapidly growing global population intensifies pressure on the environment" (PETRULAITYTE et al., 2019, p.8).

On this background, the Product-Service Systems are a strategy to shift how a product is used and designed from physical products only to a system of products and services which are jointly capable of fulfilling the wants and needs of a client with higher added value and smaller environmental impact (MANZINI; VEZZOLI; CLARK., 2017; MANZINI; VEZZOLI, 2003). Whenever aiming for accessible products and services, it is crucial to understand accessibility issues and learn how people with disabilities interact with these products and services (HENRY, 2007). The Product-Service System have a user-centered approach, which is the best way to talk and understand the customer and their needs.

Considering this scenario, the overall aim of the research reported in this article is to investigate how design combined with PSS can develop solutions to improve the life experience of people with visual impairments. The specific objectives are: to deeply analyze and explore Product-Service System, design for accessibility, visual impairment, and assistive technology; understand and describe a case study that applies the concepts studied; analyze results and stimulate new discussions on the subject. The research reported here started with the data collection of theoretical knowledge, including design and Product-Service System, visual impairment, and assistive technology. Later, a study of a case illustrates the potential of PSS to improve user experience.

\section{METHOD}

The research conducted was qualitative, applied, and exploratory-descriptive. It was divided into three main methodological steps. The first one was the state of the art step, characterized as immersion within the subjects that would be addressed in the project, which was constituted in the deepening of the theoretical framework. The "desk" research was the primary tool used in this step, by giving "references of trends in the area studied in Brazil and abroad, as well as inputs of analogous themes that can help in understanding the subject worked" (VIANNA et al. 2010, p. 22, our translation).

The second step was a background study, which is a process of deepening in the user's behavior and in the understanding of the scenario to be worked using a case study as an example. Finally, in the end, it is presented a description and discussion of the results with the main objective of covering how Product-Service System and Design combined can bring contributions to people with visual impairment.

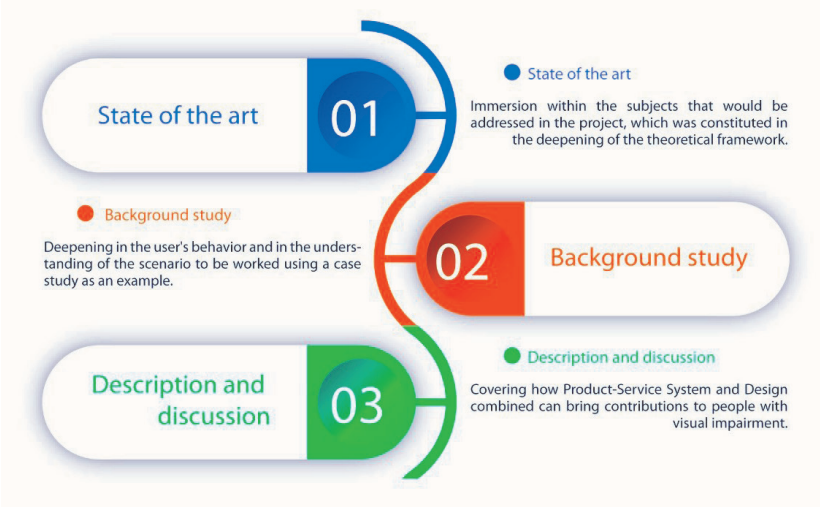

Figure 1 - Method Flowchart.

Source: Ours (2019)

\section{VISUAL IMPAIRMENT AND ASSISTIVE TECHNOLOGY}

The society took a very long time to give legal rights to people with any kind of disability. It was only in the second half of the 20th century, especially after World War II and during the Vietnam War, that some attention from international society started being given to the treatment, rehabilitation and social integration of people with disabilities (IBGE, 2018).

According to data taken from Decree No. 3,298 of 20.12.1999, with updates to Decree No. 5,296 of 02.12.2004, IBGE (2018, p.119, our translation):

Visual Impairment can be defined by blindness, in which visual acuity is equal to or less than 0.05 in the best eye, with the best optical correction; low vision, which means visual acuity between 0.3 and 0.05 in the best eye, with the best optical correction; cases in which the sum of the visual field measurement in both eyes is equal to or less than 60\%; or the simultaneous occurrence of any of the preceding conditions. 
As reported by the 2010 IBGE census, in Brazil, among $6,7 \%$ of the people with disabilities, $3,4 \%$ are visually impaired (IBGE, 2018). This data means that more than half of people with disabilities are visually impaired. This number brings us alarming questions: are those people assisted by technology? Do they know what kind of accessibility is available for improving their daily activities? Most of the currently available technologies are expensive and hard to find or to learn how to use, so most of the visually impaired population only has access to those devices in specialized places or helping centers like Dorina Nowill Foundation for Visual Impaired (São Paulo, Brazil).

According to the World Report on Disability 2010 and Vision 2020 data, every five seconds, a person becomes blind in the world. Besides, from all the cases of blindness, $90 \%$ occurs in emerging and underdeveloped countries. It is estimated that until 2020, the number of visually impaired people could be twice as the current one. However, the World Health Organization (WHO) shows that $80 \%$ of the blindness cases could be avoided through a more significant number of effective prevention and treatment actions. Still, according to WHO, about 36 million people in the world are blind, and 217 million have low vision.

Considering the extent of this population, it is essential to develop products and services specialized in attending the needs of people with visual impairment. One alternative is the Assistive Technology, a brand new term used to identify resources and services that may contribute to provide or improve functional skills of people with disabilities and, consequently, allow these people to have an independent life (FUNDAÇÃO DORINA NOWILL PARA CEGOS, n.d.).

Technical aid is understood to be any product, instrument, strategy, service, and practice used by people with disabilities and older people, mainly, produced or usually available to prevent, compensate, relieve or neutralize a deficiency, disability, or disadvantage, improving the autonomy and life's quality of these people (PORTUGAL, 2007 apud BERSCH, 2017, p. 3, our translation).

We can conclude by observing the presented data that, with more information, people can prevent their conditions. Speaking of those who already have a visual impairment, information can improve their lives with some expert advice and help. These pieces of conclusion were presented in the execution of the case study discussed in this article.

\subsection{Product-Service System Design}

The Product-Service System (PSS) is a way to "provide a highly customized integrated solution through dynamic collaborations within value networks" (RASOULLI et al., 2016, p.1). The PSS dialogs with the growing culture and economy called collaborative consumption, which has the power to revolutionize how we use products and services and, by doing so, changes the way we connect and experience these integrated solutions (BOTSMAN, 2011). The main objective of the PSS is that all the three stakeholder groups (customer, company, and society) benefit from the service system related to each one of these dimensions (MCALOONE; ANDREASEN, 2002).

Because PSS is a combination of product and service, it is necessary to contextualize these two terms. A designed product, as reported by McAloone and Andreasen (2002), focuses on the man/machine interaction upon the utilization process (distribution, sale, and use). Vargo and Lusch (2004, p.3) define service "as the application of specialized competences (knowledge and skills) through deeds, processes, and performances for the benefit of another entity or the entity itself." In the current contemporary background with continued geometric population growth and a worldwide economy based on produce-use-discard, the society has been facing a scarcity of essential resources, changing basic cycles of nature and extreme climate changes. To face these problems, a new model starts to emerge to replace this path towards a more effective and lasting development model based on use instead of ownership (VARGO; LUSCH, 2004; VEZZOLI et al., 2018). On this new path, sustainable development, PSS, collaborative economy, technology, and design walk side by side.

About sustainable development, Vezzoli et al. (2018) stated that the term refers to systemic conditions where the planetary and local social sphere and economic development occurs within the limits of environmental resilience, ensuring the natural capital that will be passed on to future generation and within the principle of equitable distribution of global natural resources. To adopt a PSS, it is essential to consider the basis of sustainable development and design for sustainability.

At the center of both design and PSS is the integration of stakeholders. To understand the user's needs and wants it is necessary to work with them, exploring their habits and daily activities. When it comes to accessibility, this integration is valuable. A key resource to design for accessibility is understanding the barriers that make a product or service difficult or impossible for many people with disabilities to use (HENRY, 2007). 


\section{CASE STUDY}

\subsection{Background}

The case related here was part of a post graduation's discipline on Product-Service System Design, which was aligned to the III Pilot Course on PSS Design offered by the Brazilian hub of the Learning Network on Sustainability (LeNS). This course was focused on Health in Housing of Social Interest and offered simultaneously by four other Brazilian Universities, each of which developed a product-service system concept that satisfies the health needs of fragile and marginalized populations.

At the State University of São Paulo (UNESP), located in Bauru, the Lar Escola Santa Luzia para Cegos (Santa Luzia Home-school for the Blind) was chosen because of an ongoing research partnership. The Lar Escola is an entity that, since 1969, offers socio-educational activities for the visually impaired. It is a local reference in teaching daily activities, providing a place where people with visual impairment can socialize and exchange experiences. The Lar Escola currently receives 74 people with visual impairment, including total blindness and low vision. The majority is 50 to 64 years old (19 people) and above 65 years old (15 people). In conclusion, most of the people that frequent the Lar Escola are middle-aged and old-aged.

In the case study reported and analyzed here, the group working with Lar Escola Santa Luzia decided to create a product-service system concept that explores the mental and social health, stimulating their social interaction. The research and design processes that led to this output is reported in the next section.

\subsection{Research process}

The research started with exploring the problem, understanding what the Lar Escola is, whom they receive, what kind of visual impairment do they deal mostly, and what the field of design combined with the product-service system could do to improve their daily experience. Firstly, the design team analyzed the data from interviews conducted previously, with 16 of the people attended by the Lar Escola. When asked about technology, 14 out of the 16 interviewed said that they use smartphones that have adapted interfaces and apps for their disabilities. Then, the design team organized a focus group with five people attended by the Lar Escola, which allowed them to understand in depth what are the difficulties, the routine, the relationship with friends and family, as well as other needs in general.

While exploring the problems and the answers, the design team realized that people who lost their entire or part of their vision, mostly adapt and accept the condition earlier than their relatives. The group also realized that the visually impaired (V.I.) wants autonomy, but also needs help to perform some specific activities that are too hard or dangerous for them to do by themselves. About the relatives, the V.I. also stated that they usually are overprotective and sometimes ashamed of their condition.

\subsection{Design process}

From the information collected during the research it was noticed that V.I. people, despite having their autonomy at home, did not have that much confidence to navigate the city. The main reason pointed by them is because places like stores or restaurants are not prepared for their deficiency and the public pass ways are full of holes and hazards. Secondly, they have no company or their relatives are scared of letting them go outside by themselves. The design team then realized that most of these relatives are overprotective or absent, so not only the V.I., but their families also needed support and access to information.

All the pieces of information collected led the design process of the product-service system solution towards the development of a conceptual app for networking. The value propositions of the app is giving information about the visual impairment, the causes, the symptoms, precautions, sharing experience with both V.I. and relatives about how they can deal with the situation, helping those who have difficulties accepting the new condition; support; social connection, connecting them with specialized services, simply and practically.

The app, named Teçá, what is a Brazilian indigenous word meaning "the one with attentive eyes", aims to gather education, services, recreation, shopping, work, sports, mental health and physical health in a collaborative network that involves not only the visually impaired, but also their family, health and education professionals, community, volunteers, enterprise content management and supportive local enterprises. To represent the app concept, the design team developed the two schemes presented above. 


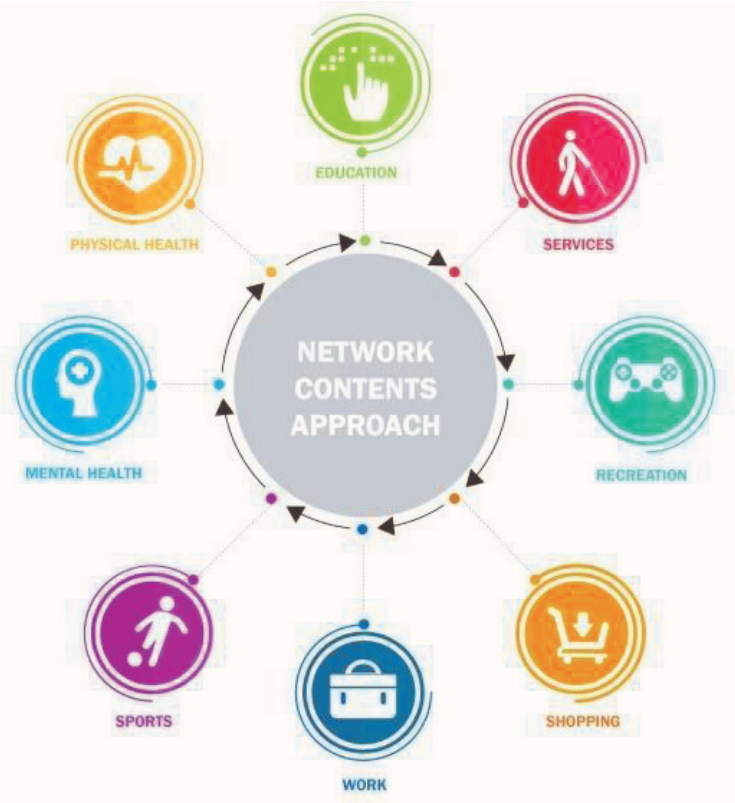

STRUCTURE OF NETWORK FUNCTIONS

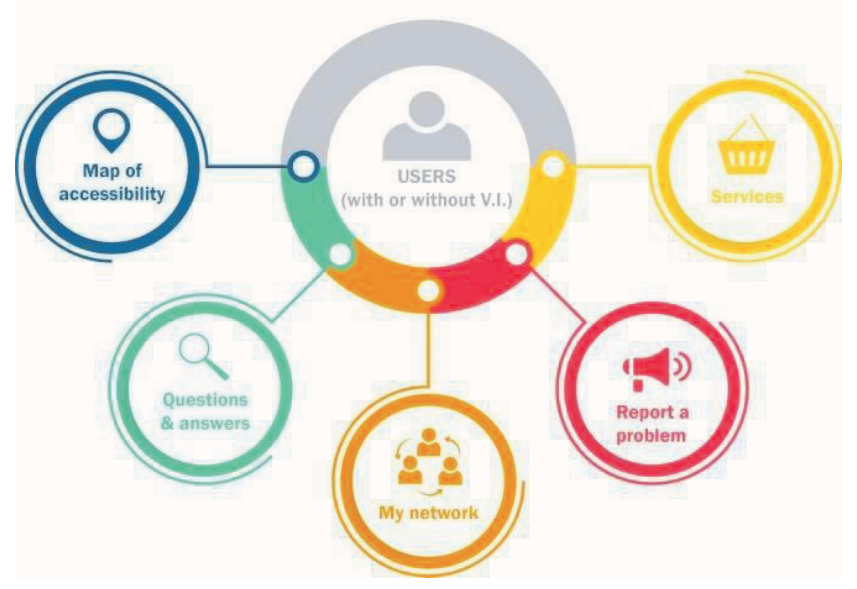

Figure 2 and 3 - Network Contents Approach and Structure of Network Functions. Source: Ours (2019)

The design process of the conceptual app was made using the most important tools of PSS. The first step was creating eight personas to better visualize the profiles of people attended by the Lar Escola. A persona is a tool used to understand the target audience by identifying user attributes, what they say, do, think, feel, and then forming a fictional (but feasible) character, and story to personify the archetype (VIANNA, 2012). For this case, four personas were V.I., seniors and middle-aged people of which the majority acquired their visual impairments along with their lives, which is more common than birth blindness. The other four personas were related to the V.I. (parents, wives, husbands, offspring), because the design group realized that the V.I. closer relationships were also affected by their relative's condition due to lack of information. After that, a tool named tomorrow headline was used (Figure 3). This uses an abductive logic, where future headlines of a newspaper are used to synthesize on text and images a PSS idea.

\section{BAURUNEWS}

Supportive Network helps visually impaired people to learn new activities.

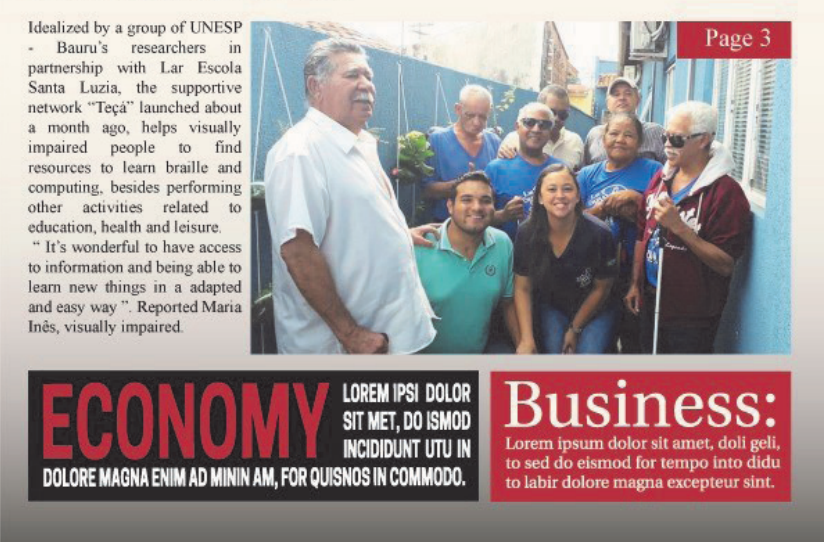

Figure 4 - Tomorrow Headline.

Source: Ours (2019)

Continuing with the development of the project, the design team created a Stakeholder Map (Figure 4), a tool used to visualize the representation of the PSS's various stakeholders, their level of interest in the company and their importance to the company.

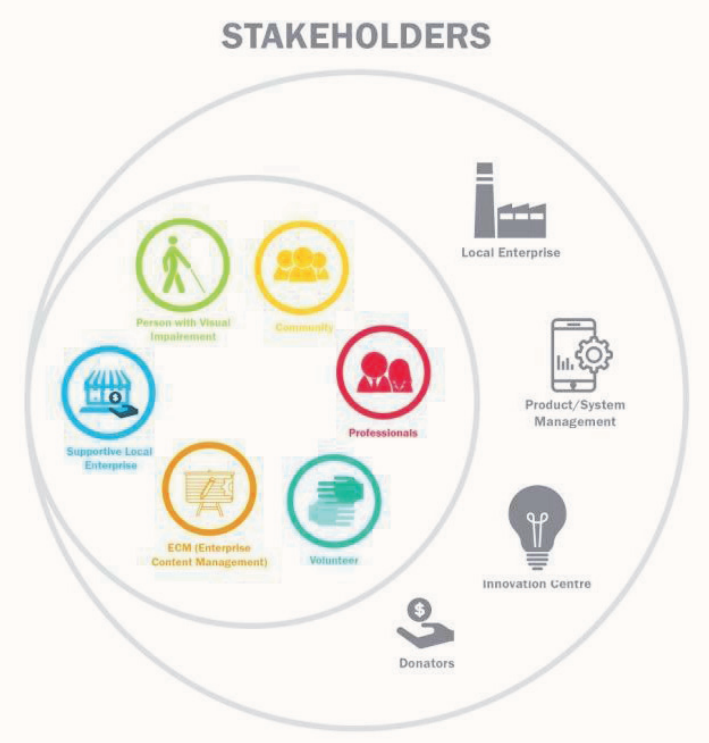

Figure 5 - Stakeholders Map.

Source: Ours (2019) 
The next tool used was a System Map (Figure 5), a synthetic representation that shows in one single frame all the different actors involved in service delivery, and their mutual links (e.g., flows of materials, energy, information, money, documents, etc.). The system map clarifies how the different service components and roles are connected, highlighting the values they exchange (SERVICE DESIGN TOOLS, n.d.).

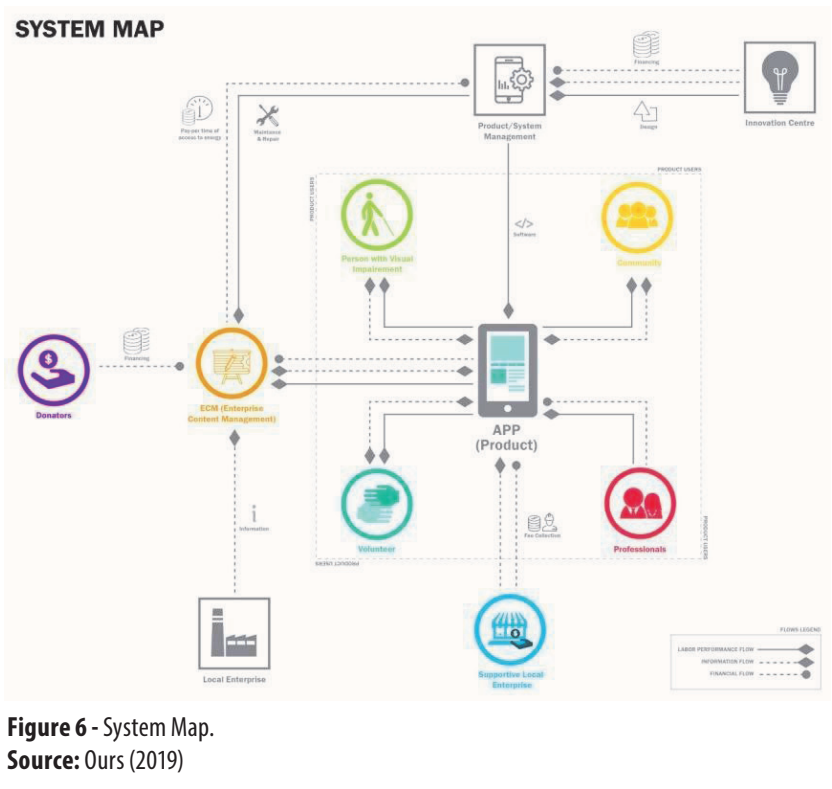

The design team also created a business model canvas, a development solution for the app interface, and a storyboard simulating the app in use. At the end of the design process, the team also applied the Sustainability Design-Orienting toolkit (SDO), which helps to orientate the system design process towards more sustainable solutions and also enables to analyze the developed solutions regarding principles applied to the three dimensions of sustainability: environmental, socio-ethical, and economic. The SDO was then used to compare the Teçá app with one of the most popular assistive apps, the Be My Eyes.

\subsection{Design and PSS contribution to visual impairment}

The designing process considers the users in all aspects, from understanding what they need to an in-depth analysis of the universe in which they are inserted. It is crucial to consider accessibility early throughout the design stages, which increases the positive impact that accessibility can have on design overall (HENRY, 2007). It is equally important to consider the core elements of the PSS process, such as user satisfaction, social demands and the limits of environmental resilience, aiming to carry out a unity of satisfaction, that is the end result desired by the user (VEZZOLI et al., 2018). Furthermore, all the stakeholders involved in the process need to understand accessibility issues.

Society is not yet prepared to welcome people with any disability. For them, simple daily actions can be dangerous, like walking down the street. In this sense, the stores, restaurants, hospitals, and all other public spaces need to improve their accessibility too. Current, people with visual impairment do not have a voice in our society, but they need to speak, and the design can listen to them, since "participatory design has become an important approach for assessing the needs of potential users, such as the visually impaired" (PHILLIPS; PROULX, 2018, p.86). To understand accessibility guidelines and learn how people with disabilities interact with everyday products, it is necessary to work side by side with them (HENRY, 2007). The PSS can help designers because "breakthrough ideas often come when people look at the world through a fresh lens" (THACKARA, 2005, p.17). Since PSS Design focuses on services, systems, situations, and people, not only on things, it can provide the fresh lens needed to answer the yearnings of people with disabilities.

When we talk about people with disabilities, it is essential to think thoroughly in each detail of the user's problems and needs. As stated, the main objective of the PSS is that all groups benefit from the service system. It is not a project based on only one of the stakeholders involved, like a company or an individual client; all of the involved people, enterprises, or institutions must be considered. Moreover, the combination of PSS solutions with assistive technology has great potential to attend the needs of people with visual impairment.

For assistive technology to successfully support visually impaired individuals, a greater focus should be given to designing technology that supports social interaction. (...) Ultimately, assistive technology should be designed so that visually impaired individuals can interact with sighted peers without the latter recognizing their disability because of the functional benefits it provides or noticing the assistive technology itself because of how subtle and socially acceptable it is. (PHILLIPS; PROULX, 2018, p. 85).

The interaction between the stakeholders is the most critical function of assistive technologies, and PSS, through a higher view, can manage to make these interactions work and complete each other successfully. 


\section{FINAL CONSIDERATIONS}

The research reported here has reviewed the state of the art in the application of PSS design, visual impairment, and assistive technology. Next, using a case study as an example, it was possible to understand the procedures of PSS design and how this design approach can contribute to developing solutions for people with disabilities that benefits all the stakeholders involved in the supply and demand system. The developed app, Teçá, has not still been placed on the market, so it is not yet in use. Because of this, this article has a limitation regarding the analysis of the app's real contributions in use. Nevertheless, the case study provides valuable insights to understand how to apply PSS design with a focus on people with disabilities.

In the case study presented here, the app concept was developed using all the PSS design steps. Firstly it was studied the context and the visual impairment issues. Secondly, the users were listened to identify their difficulties and the needs in their daily routine. Then, the main problems were detected and brought in conversation; all the parties were considered and put as equally important. Then finally, after all the PSS Design steps were taken, the result was a great network involving and benefiting all the peers.

The design process could not have happened without the interviews and the focus group conversation. Sometimes the user cannot tell what they need or want, but by asking the right questions, the designer can have this answer at the end of the conversation; it is all about looking at the process through empathetic lenses.

Contemporary time is the time of consumption and impatience. Faced with a growing offer of products, people are looking for that one that has a story that can provide experience and stimulates exchange. To design new products in contemporary society, it is essential to design with the user, considering him or her in the center of the process. The population of minorities, including people with disabilities, face difficulties that need to be overcome. Design combined with PSS can provide simple solutions without requiring complex design processes, in which everyone involved in a system can be considered in a careful and effective way. Thus, the PSS offers great contribution to the design of new products and services for the visually impaired, pondering the new social outlines.

\section{REFERENCES}

BERSCH, R. Introdução à Tecnologia Assistiva. Assistiva - Tecnologia e Educação, Porto Alegre, 2017. BOTSMAN, R. Ideas for modern living: collaborative consumption. 2011. Retrivied from: https://www. theguardian.com/lifeandstyle/2011/jan/30/ideas-modern-living-collaborative-consumptio. Access in Nov. 2019.

CARVALHO, F. J. C. et al. Economia monetária e financeira: teoria e política. 2. ed. Rio de Janeiro: Elsevier: Campus, 2007.

FUNDAÇÃODORINANOWILLPARACEGOS. Tecnologia Assistiva. n.d. Retrivied from: https://www.fundacaodorina.org.br/a-fundacao/deficiencia-visual/tecnologia-assistiva/. Access in Nov. 2019.

FUNDAÇÃO DORINA NOWILL PARA CEGOS. Homepage. n.d. Retrivied from: https://www.fundacaodorina.org.br/. Access in Nov. 2019.

HENRY, S. L. Just Ask: Integrating Accessibility Throughout Design. United States: Lulu.com, 2007.

IBGE - Instituto Brasileiro de Geografia e Estatística (Org.). Panorama nacional e internacional da produção de indicadores sociais: grupos populacionais específicos e uso do tempo. Rio de Janeiro, 2018.

KAZAZIAN, Thierry. Haverá a idade das coisas leves: design e desenvolvimento sustentável. São Paulo: Editora Senac São Paulo, 2005.

MANZINI, E.; VEZZOLI, C. A strategic design approach to develop sustainable product-service systems: examples taken from the "environmentally friendly innovation' Italian prize. Journal of Cleaner Production, v. 11(8), p. 851-857, 2003.

MANZINI, E.; VEZZOLI, C; CLARK, G. Product-service systems: using an existing concept as a new approach to sustainability. Journal of Design Research, v. 1(2), 2017. Retrivied from: https://www.inderscienceonline. com/doi/abs/10.1504/JDR.2001.009811. Access in Nov. 2019.

MCALOONE, T.; ANDREASEN, M. Defining ProductService Systems. Design for X, Beiträge Zum 13. Symposium, 2002.

PETRULAITYTE, A. Distributed Manufacturing applied to Product-Service Systems: a scenario-based design toolkit. 2019. Thesis (Doctorate in Design) - Department of Design, Brunel University, London, 2019.

PHILLIPS, M.; PROULX, M. J. Social Interaction Without Vision: an Assessment of Assistive Technology for the Visually Impaired. Technology and Innovation, v. 20, p. 85-93, 2018.

RASOULI, M. R. et al. A Dynamic Capabilities Perspective on Service-Orientation in Demand-Supply Chains. Procedia CIRP, v. 30, p. 396 - 401, 2015.

SASSANELLI, C. et al. Towards a Lean Product Service 
Systems (PSS) Design: state of the art, opportunities and challenges. Procedia CIRP, v. 30, p. 191 - 196, 2015. SERVICE DESIGN TOOLS. System Map. n.d. Retrieved from: https://servicedesigntools.org/tools/system-map. Access in Nov. 2019.

THACKARA, J. In the bubble: designing in a complex world. Cambridge: The MIT Press, 2005.

VARGO, S. L.; LUSCH, R. F. Evolving to a New Dominant Logic for Marketing. Journal of Marketing, v. 68, p. 1-17, 2004.

VEZZOLI, C. et al. Sistema produto + serviço sustentável: fundamentos. Curitiba: Insight, 2018.

VIANNA, Maurício et al. Design Thinking: inovação em negócios. Rio de Janeiro: MJV Press, 2012.

\section{AUTORES}

ORCID: https://orcid.org/0000-0001-6869-6372

RENATA DE OLIVEIRA CRUZ CARLASSARA | FAAC/UNESP Bauru, SP | Brasil | Mestranda - PPGD - Programa de PósGraduação em Design - FAAC/UNESP | Bauru, SP - Brasil |Correspondência para: Rua Ruy Mendes de Rosis, 1-145, apto. 808 - Jardim Infante Dom Henrique, Bauru - SP, 17012-636 | E-mail: renata.carlassara@unesp.br

ORCID: https://orcid.org/0000-0001-6949-0675

JÚLIA LOPES KANO|UEMG - Escola de Design |Belo Horizonte, MG - Brasil | Mestranda - PPGD - Programa de PósGraduação em Design (FAAC/UNESP) | Bauru, SP - Brasil | Correspondência para: Alameda Dr. Octávio Pinheiro Brisolla, 18-45, apto. 808 - Vila Nova Cidade Universitária, Bauru - SP, 17012-191| E-mail: julia.kano@hotmail.com

ORCID: https://orcid.org/0000-0002-1573-5590

TOMAS QUEIROZ FERREIRA BARATA, Dr. | Universidade de São Paulo | Departamento de Tecnologia da Arquitetura FAUUSP | São Paulo, SP - Brasil | Correspondência para: Rua São Benedito, 873, apto. 103, Ed. Grande Mogol, São Paulo - SP, 04735-002 | E-mail: barata@usp.br

ORCID: https://orcid.org/0000-0002-9994-6669

MONICA MOURA, Dra. | Universidade Estadual Paulista | Departamento deDesign|Bauru,SP-Brasil|Correspondência para: Rua Henrique Savi, 2-63 - Vila Nova Cidade Universitária, Bauru - SP, 17012-205| E-mail: monica.moura@unesp.br

ORCID: 0000-0001-9219-0363

IANA ULIANA PEREZ, M.Sc. | Universidade Estadual Paulista | Doutorado em Design | Bauru, SP - Brasil | Correspondência para:Rua HenriqueSavi, 14-44-Vila Nova CidadeUniversitária, Bauru - SP, 17012-205 | E-mail: iana.uli@gmail.com

\section{COMO CITAR ESTE ARTIGO}

CARLASSARA, Renata de Oliveira Cruz; KANO, Júlia Lopes; BARATA, Tomas Queiroz Ferreira; MOURA, Monica; PEREZ, Iana Uliana. How The Design Of Product-Service Systems Can Improve The Life Of People With Visual Impairment. MIX Sustentável, [S.I.], v. 6, n. 3, p. 157-164, jun. 2020. ISSN 24473073. Disponível em:<http://www.nexos.ufsc.br/index.php/ mixsustentavel>. Acesso em: dia mês. ano. doi:https:// doi.org/10.29183/2447-3073.MIX2020.v6.n3.157-164.

DATA DE ENVI0: 12/12/2019

DATA DE ACEITE: 20/06/2020 